\section{JURNAL EKONOMI EFEKTIF}

ISSN : $2622-8882$, E-ISSN : 2622-9935

Jurnal Ekonomi Efektif, Vol. 1, No. 4, Juli 2019

@ Prodi Manajemen Fakultas Ekonomi Universitas

Pamulang

\title{
PENGARUH KEGIATAN PROMOSI TERHADAP KEPUTUSAN PEMBELIAN KONSUMEN PADA PT. MODISE BUSANA SEJATI DI BANDUNG
}

\author{
${ }^{1 *}$ Heri Erlangga, ${ }^{2}$ Jasmani, ${ }^{3}$ Nurjaya \\ ${ }^{1}$ Universitas Pasundan, Bandung, Jawa Barat, Indonesia \\ ${ }^{2}$ Universitas Pamulang, Tangerang Selatan, Banten, Indonesia \\ ${ }^{3}$ Universitas Suryakancana, Cianjur, Jawa Barat, Indonesia \\ *heri.erlangga@unpas.ac.id
}

\begin{abstract}
ABSTRAK
Penelitian ini bertujuan untuk mengetahui pengaruh Kegiatan Promosi terhadap Keputusan pembelian Konsumen pada PT. Modise Busana Sejati di Bandung. Metode yang digunakan adalah explanatory research dengan sampel sebanyak 96 responden. Teknik analisis menggunakan analisis statistik dengan pengujian regresi, korelasi, determinasi dan uji hipotesis. Hasil penelitian ini variabel Kegiatan Promosi diperoleh nilai rata-rata skor sebesar 3,417 dengan kriteria baik. Variabel Keputusan pembelian Konsumen diperoleh nilai rata-rata skor sebesar 3,839 dengan kriteria baik. Kegiatan Promosi berpengaruh positif dan signifikan terhadap Keputusan pembelian Konsumen dengan nilai persamaan regresi $\mathrm{Y}=9,192+0,854 \mathrm{X}$, dan nilai koefisien korelasi 0,776 atau memiliki tingkat hubungan yang kuat dengan nilai determinasi 60,2\%. Uji hipotesis diperoleh signifikansi $0,000<0,05$.
\end{abstract}

Kata Kunci: Kegiatan Promosi, Keputusan Pembelian Konsumen.

\section{ABSTRACT}

This study aims to determine the effect of promotional activities on consumer purchasing decisions at PT. Real Fashion Fashion in Bandung. The method used is explanatory research with a sample of 96 respondents. The analysis technique uses statistical analysis with regression testing, correlation, determination and hypothesis testing. The results of this research variable Promotion Activities obtained an average score of 3,417 with good criteria. Consumer purchasing decision variable obtained an average score of 3.839 with good criteria. Promotion activity has a positive and significant effect on consumer purchasing decisions with a regression equation value of $Y=9.192+0.854 X$, and a correlation coefficient value of 0.776 or has a strong level of relationship with a determination value of $60.2 \%$. Hypothesis testing obtained a significance of $0.000<0.05$.

Keywords: Promotion Activities, Consumer Purchasing Decisions. 


\section{PENDAHULUAN}

\section{A. Latar Belakang Masalah}

Pakaian merupakan salah satu kebutuhan pokok sehari-hari konsumen. Untuk memenuhi kebutuhan tersebut konsumen membelinya dari toko-toko terdekat. PT. Modise Busana Sejati merupakan agen grosir pakaian yang menjual produk dengan cara online maupun offline yang menjual dalam jumlah besar maupun satuan dengan sistem ini PT. Modise Busana Sejati dapat menyuplai pakaian baik didalam maupun diluar wilayah Depok melalui sistem penjulan secara langsung maupun tidak langsung.

Namun kini penjualan melalui media online begitu marak dan perkembangannya begitu pesat sehingga persaingan yang dihadapi PT. Modise Busana Sejati sangatlah tajam sehingga diperlukan strategi-strategi yang mampu bersaing. Oleh karena itu pemasaran merupakan salah satu tujuan yang paling penting terhadap penjualan suatu produk. Berhasil atau tidaknya kehidupan suatu perusahaan tergantung dari hasil penjualan yang dilakukan perusahaan tersebut.

Faktor promosi yang dilakukan oleh perusahaan menjadi sangat penting karena promosi merupakan suatu bentuk komunikasi pemasaran, dimana komunikasi pemasaran adalah aktivitas pemasaran yang berusaha menyebarkan informasi, mempengaruhi, membujuk mengingatkan pasar atas perusahaan atau produknya agar bersedia menerima, membeli dan loyal pada produk yang ditawarkan, (Fandy Tjiptono, 2007:103).

Setiap usaha atau langkah yang dilakukan perusahaan adalah untuk memuaskan konsumen, perusahaan dituntut untuk melakukan strategi pemasaran yang tepat agar mempunyai suatu produk yang memiliki keunggulan dari pesaingnya dan juga perusahaan harus menyampaikan informasi tentang produk-produknya agar dapat menarik konsumen yang potensial sehingga dapat mempertahankan dan meningkatkan hasil penjualan perusahaan.

Salah satu kegiatan pemasaran yang cukup efektif dan efisien adalah promosi. Menurut Rangkuti (2014), promosi adalah "Kegiatan penjualan dan pemasaran dalam rangka menginformasikan dan mendorong permintaan terhadap produk, jasa dan ide dari perusahaan dengan cara mempengaruhi konsumen agar mau membeli produk dan jasa yang dihasilkan oleh perusahaan".

Promosi merupakan salah satu faktor yang sangat penting, karena promosi dapat mempengaruhi secara langsung terhadap kelancaran maupun keberhasilan perusahaan dalam mencapai tujuannya. Oleh karena itu kelancaran maupun keberhasilan suatu perusahaan sangat tergantung pada manajemen didalam membuat rencana kegiatan promosi yang akan datang, baik jangka pendek maupun jangka panjang.

Dengan adanya promosi yang terencana, maka perusahaan dapat mendekati pembeli atau calon konsumen agar mau membeli produk yang mereka tawarkan. Disamping itu promosi erat kaitannya dengan kelangsungan hidup suatu perusahaan. Promosi yang berhasil sebenarnya tidak hanya mampu meningkatkan hasil penjualan semata-mata, akan tetapi dapat memberikan keuntungan-keuntungan lain seperti nama perusahaan akan dikenal oleh konsumen dan hasil produksinya dapat meningkatkan efisiensi penggunaan modal kerja, memperkecil piutang, dan lain-lain. Dan sebaliknya jika strategi tidak berhasil, maka dapat menyebabkan kenaikan biaya per unit, keuntungan yang diperoleh dalam tiap unit menurun sehingga dengan sendirinya penghasilan perbulan pun menurun.

Masih banyak konsumen yang belum mengetahui secara jelas tentang berbagai macam produk yang dimiliki PT. Modise Busana Sejati, untuk itu diharapkan kegiatankegiatan promosi yang dilakukan dapat mengenai sasaran dengan tepat, guna memberikan informasi mengenai produk pakaian secara jelas, sehingga konsumen mendapatkan informasi yang dalam mengenai produk pakaian di PT. Modise Busana Sejati, promosi 
dimaksudkan untuk menarik keputusan pembelian konsumen, antara lain dengan memberikan informasi selengkapnya kepada konsumen akan suatu produk yang dipasarkan. Jika kegiatan promosi terlaksana dengan baik, maka konsumen akan tertarik dan akan membeli produk tersebut. Cara memperkenalkan produk terhadap konsumen dapat mengadakan acara-acara promosi seperti sosialisasi produk, pameran, sharing session produk didaerah-daerah yang lebih luas lagi jangkauannya dan masih banyak lagi acara lainnya yang dapat dilaksanakan guna memperkenalkan produk kepada konsumen.

Diharapkan dengan dilaksanakanya kegiatan promosi, keputusan pembelian konsumen akan meningkat, dikarenakan dengan tumbuhnya rasa tertarik konsumen akan produk yang ditawarkan pada acara-acara promosi yang diselengarakan tersebut. Dalam berbagai kegiatan promosi yang dilakukan PT. Modise Busana Sejati sebisa mungkin sebagai penyelenggara acara, harus dapat membuat kegiatan promosi menjadi menarik, contohnya dengan membuat acara-acara, dari menentukan tema acara yang unik, penampilan untuk menayangkan informasi produk yang dipromosikan menggunakan design slide yang menarik, sound effect yang berkualitas, sampai dengan pembagian souvenir kepada para pengunjung acara. Diharapkan kegiatan promosi tersebut memiliki daya tarik yang kuat bagi konsumen untuk memutuskan membeli produknya.

Maka dari itu promosi memegang Penting dalam dalam mencapai tujuan perusahaan terutama dalam mendapatkan keuntungan maksimal dengan biaya terkecil. Promosi merupakan kegiatan pokok yang dilakukan pengusaha untuk kelangsungkan hidup perusahaan yang selanjutnya berkembang dan mencapai hasil penjualan yang diinginkan, sehingga dapat diartikan bahwa kepuasan konsumen merupakan suatu keadaan dimana keinginan dan harapan konsumen dapat terpenuhi.

Kegiatan promosi dilakukan guna memberikan informasi kepada konsumen yang masih belum mengenal produk secara jelas, didukung dengan penyajian program-program promosi lainnya yang berhubungan dengan produk yang dipasarkan. Hal ini diharapkan dapat menorong keputusan pembelian konsumen akan suatu produk, keputusan pembelian konsumen diharapkan akan berubah, dari yang sebelumnya tidak berminat untuk membeli menjadi berminat untuk membeli. Effendy (Effendy, 2003:305) mendefinisikan minat sebaga "Kelanjutan dari perhatian yang merupakan titik tolak bagi timbulnya hasrat (desire) untuk melakukan suatu kegiatan yang diharapkan komunikator". Hal yang kontradiktif justru terjadi di perusahaan diantaranya kegiatan-kegiatan promosi yang dilakukan PT. Modise Busana Sejati dalam mempengaruhi keputusan pembelian konsumen masih sangat minim, keputusan pembelian konsumen cenderung berkurang sehingga mengurangi omzet penjualan.

Hal ini dipengaruhi oleh kegiatan yang dilakukan contohnya menyelenggrakan program sosialisasi produk sebagai ajang memberikan informasi mengenai produk lama yang sudah ada dengan tujuan agar manfaat dari produk dapat digunakan dengan baik dan benar oleh konsumen, selain itu untuk menarik minat konsumen PT. Modise Busana Sejati juga meyelenggarakan acara- acara untuk memperkenalkan produk barunya. Cara ini dimaksudkan untuk memberikan gambaran terhadap konsumen akan produk, dan agar lebih menarik perhatian konsumen, penyelenggaraan disarankan dapat menyediakan berbagai macam hadiah yang dapat menarik minat konsumen. Dengan demikian penulis tertarik untuk mengadakan riset lebih lanjut, adapun judul penelitian yang penulis lakukan adalah "Pengaruh Kegiatan Promosi Terhadap Keputusan pembelian Konsumen Pada PT. Modise Busana Sejati di Bandung"

\section{B. Rumusan Masalah}

1. Bagaimana Kegiatan Promosi pada PT. Modise Busana Sejati di Bandung?. 
2. Bagaimana Keputusan pembelian Konsumen pada PT. Modise Busana Sejati di Bandung ?.

3. Adakah pengaruh antara Kegiatan Promosi terhadap Keputusan pembelian Konsumen pada PT. Modise Busana Sejati di Bandung ?.

\section{Tujuan Penelitian}

1. Untuk mengetahui kondisi Kegiatan Promosi pada PT. Modise Busana Sejati di Bandung.

2. Untuk mengetahui kondisi Keputusan pembelian Konsumen pada PT. Modise Busana Sejati di Bandung.

3. Untuk mengetahui pengaruh antara Kegiatan Promosi terhadap Keputusan pembelian Konsumen pada PT. Modise Busana Sejati di Bandung.

\section{TINJAUAN PUSTAKA}

\section{Kegiatan Promosi}

Menuurut Kotler dan Keller (2017:263) berpendapat "Promosi merupakan ramuan khusus dari iklan pribadi, promosi penjualan dan hubungan masyarakat yang digunakan perusahaan untuk mencapai tujuan iklan dan pemasarannya”. Sedangkan Babin (2017:26) "Promosi merupakan fungsi komunikasi dari perusahaan yang bertanggung jawab menginformasikan dan membujuk/mengajak pembeli". Lain halnya dengan Tjiptono (2017:229) "Promosi penjualan adalah bentuk persuasi langsung melalui penggunaan berbagai insentif yang dapat diatur untuk merangsang pembelian produk dengan segera dan meningkatkan jumlah barang yang dibeli konsumen".

\section{Keputusan pembelian Konsumen}

Menurut Mowen (2017:24) berpendapat "Keputusan pembelian adalah sesuatu diperoleh dari proses belajar dan proses pemikiran yang yang membentuk suatu persepsi". Keputusan pembelian ini menciptakan suatu motivasi yang terus terekam dalam benaknya dan menjadi suatu keinginan yang sangat kuat yang pada akhirnya ketika seorang konsumen harus memenuhi kebutuhannya akan mengaktualisasikan apa yang ada didalam benaknya itu. Sedangkan menurut Kinnear dan Taylor (2011:26), "Keputusan pembelian merupakan bagian dari komponen perilaku konsumen dalam sikap mengkonsumsi, kecenderungan responden untuk bertindak sebelum keputusan membeli benar-benar dilaksanakan".

\section{METODE PENELITIAN}

\section{Populasi}

Populasi dalam penelitian ini berjumlah 96 responden PT. Modise Busana Sejati di Bandung

\section{Sampel}

Teknik pengambilan sampling dalam penelitian ini adalah sampel jenuh, dimana semua anggota populasi dijadikan sebagai sampel. Dengan demikian sampel dalam penelitian ini sampel yang digunakan berjumlah 96 responden.

\section{Jenis Penelitian}

Jenis penelitian yang dipakai adalah asosiatif, dimana tujuannya adalah untuk mengetahui atau mencari keterhubungan antara variabel independen terhadap variabel dependennya

\section{Metode Analisis Data}

Dalam menganalisis data digunakan uji validitas, uji reliabilitas, analisis regresi linier 
sederhana, analisis koefisien korelasi, analisis koefisien determinasi dan pengujian hipotesis.

\section{HASIL PENELITIAN}

\section{Analisis Deskriptif}

Pada pengujian ini digunakan untuk mengetahui skor minimum dan maksimum skor tertinggi, ratting score dan standar deviasi dari masing-masing variabel. Adapun hasilnya sebagai berikut:

Tabel 1. Hasil Analisis Descriptive Statistics

\section{Descriptive Statistics}

\begin{tabular}{l|r|r|r|r|r} 
& N & Minimum & Maximum & Mean & \multicolumn{1}{c}{ Std. Deviation } \\
\hline Kegiatan Promosi (X) & 96 & 28 & 44 & 34.17 & 3.892 \\
\hline Keputusan pembelian (Y) & 96 & 29 & 49 & 38.39 & 4.286 \\
\hline Valid N (listwise) & 96 & & & & \\
\hline
\end{tabular}

Kegiatan Promosi diperoleh varians minimum sebesar 28 dan varians maximum 44 dengan ratting score sebesar 3,417 dengan standar deviasi 3,895. Skor ini termasuk pada rentang sakala 3,40 - 4,19 dengan kriteria baik atau setuju.

Keputusan pembelian Konsumen diperoleh varians minimum sebesar 29 dan varians maximum 49 dengan ratting score sebesar 3,839 dengan standar deviasi 3,968. Skor ini termasuk pada rentang sakala 3,40-4,19 dengan kriteria baik atau setuju.

\section{Analisis Verifikatif.}

Pada analisis ini dimaksudkan untuk mengetahui pengaruh variabel independen terhadap variabel dependen. Adapun hasil pengujian sebagai berikut:

\section{a. Analisis Regresi Linier Sederhana}

Uji regresi ini dimaksudkan untuk mengetahui perubahan variabel dependen jika variabel independen mengalami perubahan. Adapun hasil pengujiannya sebagai berikut:

Tabel 2. Hasil Pengujian Regresi Linier Sederhana

\begin{tabular}{|c|c|c|c|c|c|c|}
\hline \multicolumn{7}{|c|}{ Coefficients $^{a}$} \\
\hline \multirow{2}{*}{\multicolumn{2}{|c|}{ Model }} & \multicolumn{2}{|c|}{$\begin{array}{l}\text { Unstandardized } \\
\text { Coefficients }\end{array}$} & \multirow{2}{*}{$\begin{array}{l}\text { Standardized } \\
\text { Coefficients } \\
\text { Beta }\end{array}$} & \multirow[b]{2}{*}{$\mathrm{t}$} & \multirow[b]{2}{*}{ Sig. } \\
\hline & & $\mathrm{B}$ & Std. Error & & & \\
\hline & (Constant) & 9.192 & 2.463 & & 3.733 & .000 \\
\hline & Kegiatan Promosi (X) & .854 & .072 & .776 & 11.931 & .000 \\
\hline
\end{tabular}

a. Dependent Variable: Keputusan Pembelian (Y)

Berdasarkan hasil pengujian pada tabel di atas, diperoleh persamaan regresi $\mathrm{Y}=$ $9,192+0,854 X$. Dari persamaan tersebut dijelaskan sebagai berikut:

1) Konstanta sebesar 9,192 diartikan jika Kegiatan Promosi tidak ada, maka telah terdapat nilai Keputusan pembelian Konsumen sebesar 9,192 point.

2) Koefisien regresi Kegiatan Promosi sebesar 0,854, angka ini positif artinya setiap ada peningkatan Kegiatan Promosi sebesar 0,854 point maka Keputusan pembelian Konsumen juga akan mengalami peningkatan sebesar 0,854 point.

\section{b. Analisis Koefisien Korelasi}

Analisis koefisien korelasi dimaksudkan untuk mengetahui tingkat kekuatan hubungan dari variabel independen terhadap variabel dependen. Adapun hasil pengujian sebagai berikut:

Tabel 3. Hasil Pengujian Koefisien Korelasi Kegiatan Promosi Terhadap Keputusan 
Pembelian Konsumen.

\begin{tabular}{llrr} 
& \multicolumn{1}{c}{ Correlations $^{\mathbf{b}}$} & \multicolumn{1}{c}{$\begin{array}{r}\text { Kegiatan } \\
\text { Promosi }(\mathrm{X})\end{array}$} & $\begin{array}{c}\text { Keputusan } \\
\text { Pembelian (Y) }\end{array}$ \\
\hline Kegiatan Promosi (X) & Pearson Correlation & 1 & $.776^{* *}$ \\
\cline { 2 - 4 } & Sig. (2-tailed) & .000 \\
\hline Keputusan Pembelian (Y) & Pearson Correlation & $.776^{* *}$ & 1 \\
\cline { 2 - 4 } & Sig. (2-tailed) & .000 & \\
\hline \multirow{2}{**}{. Correlation is significant at the 0.01 level (2-tailed). } & & \\
b. Listwise N=96 &
\end{tabular}

Berdasarkan hasil pengujian diperoleh nilai korelasi sebesar 0,776 artinya Kegiatan Promosi memiliki hubungan yang kuat terhadap Keputusan pembelian Konsumen.

\section{c. Analisis Koefisien Determinasi}

Analisis koefisien determinasi dimaksudkan untuk mengetahui besarnya persentase pengaruh dari variabel independen terhadap variabel dependen. Adapun hasil pengujian sebagai berikut:

Tabel 4. Hasil Pengujian Koefisien Determinasi Kegiatan Promosi Terhadap Keputusan Pembelian Konsumen.

\begin{tabular}{l|c|c|c|c|} 
& \multicolumn{4}{c}{ Model Summary } \\
Model & $\mathrm{R}$ & $\mathrm{Adjusted} \mathrm{R}$ & \multicolumn{2}{c}{$\begin{array}{c}\text { Std. Error of the } \\
\text { Estimate }\end{array}$} \\
\hline 1 & & R Square & Square & 2.717 \\
\hline
\end{tabular}

a. Predictors: (Constant), Kegiatan Promosi (X)

Berdasarkan hasil pengujian diperoleh nilai determinasi sebesar 0,602 artinya Kegiatan Promosi memiliki kontribusi pengaruh sebesar 60,2\% terhadap Keputusan pembelian Konsumen, sedangkan sisanya sebesar 39,8\% dipengaruhi oleh faktor lain yang tidak dilakukan penelitian.

\section{d. Uji Hipotesis}

Pengujian hipotesis dengan uji t digunakan untuk mengetahui hipotesis mana yang diterima.

Rumusan hipotesis: Terdapat pengaruh yang signifikan antara Kegiatan Promosi terhadap Keputusan pembelian Konsumen.

Tabel 5. Hasil Uji Hipotesis Kegiatan Promosi Terhadap Keputusan Pembelian Konsumen.

\begin{tabular}{|c|c|c|c|c|c|c|}
\hline & & & Coefficien & & & \\
\hline & & $\begin{array}{l}\text { Unsté } \\
\text { Co }\end{array}$ & $\begin{array}{l}\text { ndardized } \\
\text { fficients }\end{array}$ & $\begin{array}{l}\text { Standardized } \\
\text { Coefficients }\end{array}$ & & \\
\hline & del & $\mathrm{B}$ & Std. Error & Beta & $\mathrm{t}$ & Sig. \\
\hline$\overline{1}$ & (Constant) & 9.192 & 2.463 & & 3.733 & .000 \\
\hline & Kegiatan Promosi (X) & .854 & .072 & .776 & 11.931 & .000 \\
\hline
\end{tabular}

a. Dependent Variable: Keputusan Pembelian (Y)

Berdasarkan hasil pengujian pada tabel di atas, diperoleh nilai $\mathrm{t}$ hitung $>\mathrm{t}$ tabel atau $(11,931>1,985)$, dengan demikian hipotesis yang diajukan bahwa terdapat pengaruh yang signifikan atara Kegiatan Promosi terhadap Keputusan pembelian Konsumen diterima. 


\section{Pembahasan Hasil Penelitian}

\section{Kondisi Jawaban Responden Variabel Kegiatan Promosi}

Berdasarkan jawaban responden, variabel kegiatan promosi diperoleh ratting score sebesar 3,417 berada di rentang skala 3,40 - 4,19 dengan kriteria baik atau setuju.

\section{Kondisi Jawaban Responden Variabel Keputusan pembelian Konsumen}

Berdasarkan jawaban responden, variabel keputusan pembelian konsumen diperoleh ratting score sebesar 3,839 berada di rentang skala 3,40 - 4,19 dengan kriteria baik atau setuju.

\section{Pengaruh Kegiatan Promosi Terhadap Keputusan pembelian Konsumen}

Kegiatan Promosi berpengaruh signifikan terhadap Keputusan pembelian Konsumen dengan persamaan regresi $\mathrm{Y}=9,192+0,854 \mathrm{X}$, nilai korelasi sebesar 0,776 atau memiliki hubungan yang kuat dengan kontribusi pengaruh sebesar $60,2 \%$. Pengujian hipotesis diperoleh nilai $t$ hitung $>t$ tabel atau $(11,931>1,985)$. Dengan demikian hipotesis yang diajukan bahwa terdapat berpengaruh signifikan antara Kegiatan Promosi terhadap Keputusan pembelian Konsumen diterima.

\section{KESIMPULAN DAN SARAN}

\section{Kesimpulan}

a. Variabel Kegiatan Promosi diperoleh ratting score sebesar 3,417 berada di rentang skala 3,40 - 4,19 dengan kriteria baik atau setuju.

b. Variabel Keputusan pembelian Konsumen diperoleh ratting score sebesar 3,839 berada di rentang skala 3,40 - 4,19 dengan kriteria baik atau setuju.

c. Kegiatan Promosi berpengaruh signifikan terhadap Keputusan pembelian Konsumen dengan persamaan regresi $\mathrm{Y}=9,192+0,854 \mathrm{X}$, nilai korelasi sebesar 0,776 atau kuat dan kontribusi pengaruh sebesar $60,2 \%$ sedangkan sisanya sebesar $39,8 \%$ dipengaruhi faktor lain. Uji hipotesis diperoleh nilai $t$ hitung $>t$ tabel atau $(11,931>1,985)$.

\section{Saran}

Berdasarkan hasil kesimpulan, maka penulis memberikan saran sebagai berikut:

a. Kegiatan Promosi PT. Modise Busana Sejati harus lebih diperhatikan dan ditingkatkan lagi, terutama dalam hal tingkat manfaat kupon yang diberikan dan Tingkat pemberian Barang Iklan yang masih belum terlalu disukai oleh Konsumen, untuk itu PT. Modise Busana Sejati harus segera mengganti atau mengadakan perbaikan, dan jangan terlalu dibiarkan terlalu lama.

b. Keputusan pembelian Konsumen harus lebih ditumbuhkan dan ditingkatkan kembali, karena tingkat keinginan menggunakan produk serta tingkat pengaruh kualitas masih rendah maka harus dapat segera diselesaikan agar tujuan yang dicapai dapat tercapai atau bahkan melewati target yang diinginkan.

c. Kegiatan Promosi merupakan salah satu factor yang sangat mempengaruhi keputusan pembelian Konsumen, sebaiknya kegiatan promosi tersebut dapat dimaksimalkan agar keputusan pembelian konsumen dapat meningkat sehingga visi, misi dan tujuan PT. Modise Busana Sejati dapat tercapai.

\section{DAFTAR PUSTAKA}

Abdullah, M (2014) Manajemen dan Evaluasi Keputusan pembelian Konsumen, Yogyakarta: Penerbit Aswaja Pressindo.

Algifari. (2015). “Analisis Regresi untuk Bisnis dan Ekonomi”. Yogyakarta: BPFE. 
AR. Bulaeng, “Komunikasi Pemasaran”, Pusat Penerbit Universitas Terbuka, Jakarta, 2002. Arikunto, Suharsimi (2014). "Prosedur Penelitian Suatu Pendekatan Praktek". Jakarta: Rineka Cipta.

Assael, "Customer Behavior and Marketing Action", Four Edition, Kent Publishing, New York, 2002.

Bashu Swastha dan T. Handoko (2015) Manajemen Pemasaran Moderen, Yogyakarta: BPFE. Bilson Simamora (2016) Panduan Riset Prilaku Konsumen, Jakarta: PT. Gramedia Pustaka.

Effendi, Onong Uchjana," Hubungan Masyarakat Suatu Studi Komunikologis", PT. Remaja Rosdakarya, Bandung, 2003.

Erlangga, H. (2018). Spirit Pengembangan Kewirausahaan Di Perguruan Tinggi. Paradigma POLISTAAT: Jurnal Ilmu Sosial dan Ilmu Politik, 1(2), 102-127.

Fandy Tjiptono (2017), Serivce Quality and Satisfiation. Jakarta: Edisi tiga. Andi.

Freddy Rangkuti (2016) Strategi Promosi Yang Kreatif, Edisi Pertama, Cetakan Pertama Jakarta: Gramedia Pustaka Utama.

Ilham, D. (2014). Implementasi Nilai-Nilai Keagamaan pada Mata Pelajaran Umum dalam Upaya Peningkatan Akhlak Peserta Didik di MAN Malili Kabupaten Luwu Timur (Doctoral dissertation, STAIN/IAIN Palopo).

Ilham, D. (2019). Implementing Local Wisdom Values in Bride and Groom Course at KUA Bara SubDistrict, Palopo City. Jurnal Konsepsi, 8(1), 1-9.

Ilham, D. (2019). Menggagas Pendidikan Nilai dalam Sistem Pendidikan Nasional. Didaktika: Jurnal Kependidikan, 8(3), 109-122.

Imam Ghozali (2017). “Aplikasi Analisis Multivariate Dengan Program SPSS”. Edisi Kelima. Semarang: Badan Penerbit Undip.

Jasmani, J. (2018). Pengaruh Kualitas Produk Dan Harga Terhadap Keputusan Pembelian Pada PT. Baja Mandiri Di Jakarta. Disrupsi Binis, 1(1).

Kasmir, "Etika Customer Service", Raja Grafindo Persada, Jakarta, 2004.

Kharis, Ismu Fadli (2011). "Studi Mengenai Impulse Buying dalam Penjualan Online". Semarang : Skripsi Universitas Diponegoro

Kotler dan Amstrong (2017), Prinsip-prinsip Pemasaran. Edisi Kedua Belas”. Jilid Satu. Jakarta: Erlangga.

Lupiyoadi (2016) Manajemen Pemasaran Jasa, Edisi 4, Jakarta: Salemba Empat.

Lupiyoadi, “Manajemen Pemasaran Jasa”, Salemba Empat, Jakarta, 2008.

Luthans Fred (2014) Organizational Behavior, Ney York: McGraw-Hill, New York.

Muhibbib Syah, "Psikologi Belajar”, PT. Raja Grafindo Persada, Jakarta, 2003.

Mulyana, Deddy, "Metodologi Penelitian Kuantitatif”, PT. Raja Grafindo Persada, Jakarta, 2003.

Nurhayati, N. I. D. N., Hindarsah, I., Sos, S., Erlangga, H., Sos, S., \& Maun Jamaludin, I. (2018). Pelatihan Pembukuan Di UKM Sumpia Chantika Dewi Cimindi Cimahi. Laporan Program Kepakaran Fisip Unpas Pengabdian Kepada Masyarakat Tahun Akademik 2016/2017, 1-22.

Philip Kotler (2017) Manajemen Pemasaran, Edisi Keempat Belas, Jakarta: PT. Indeks.

Phipil Kotler dan Kevin Keller (2017) Manajemen Pemasaran, Edisi Kedua Belas, Jilid Satu, Jakarta: Erlangga.

Riduwan, "Metode dan Tehnik Penyusunan Proposal Penelitian", Pustaka Presindo, Jakarta, 2012.

Saladin, Djaslim, ”Manajemen Pemasaran", Linda Karya, Bandung, 2003.

Santoso, Singgih (2015). "Menguasai Statistik Multivariat". Jakarta: PT Elex Media Komputindo.

Sudjana (2014) “Metode Statistika”, Bandung: Tarsido. 
Sugiyono (2017), "Metode Penelitian Administrasi : dilengkapi dengan Metode $R \& D$ ”. Bandung: Alfabeta.

Suhartanto (2014). “Metode Riset Pemasaran”. Bandung: Alfabeta

Wiliam J. Shultz, "Marketing”, Prentice Hall Inc, Zulganef, New York, 2001.

Wiliam J. Stanton, “Prinsip Pemasaran”, Jilid Satu, Edisi Kesepuluh, Erlangga, Jakarta, 2002. 